\title{
Bridging Language Attitudes with Perceived Language Notions
}

\author{
Andreas Papapavlou, Andia Mavromati \\ University of Cyprus, Nicosia, Cyprus \\ Email: mavromati.andia@ucy.ac.cy
}

How to cite this paper: Papapavlou, A., \& Mavromati, A. (2017). Bridging Language Attitudes with Perceived Language Notions. Open Journal of Modern Linguistics, 7, 167-183.

https://doi.org/10.4236/ojml.2017.72013

Received: January 22, 2017

Accepted: April 25, 2017

Published: April 28, 2017

Copyright $\odot 2017$ by authors and Scientific Research Publishing Inc. This work is licensed under the Creative Commons Attribution International License (CC BY 4.0).

http://creativecommons.org/licenses/by/4.0/ (c) (i) Open Access

\begin{abstract}
The current study examines students' beliefs about languages in general, their overt attitudes towards Cypriot Greek and the status that is accorded to this variety. Results, from a quantitative research approach, show that the Cypriot Greek variety is in a process of changing status and it seems that it is appreciated more than in the past (Papapavlou, 1998, 2004, 2010; Tsiplakou, 2006; Ioannidou, 2009). Participants (university students) believe that languages are: a) a mirror of society and a robust means of communication, b) a reflection of the cultures of a given country, c) constantly evolving and adjusting to the needs of a society, and d) an image of our way of thinking and interacting in society. However, participants do not agree that language is the only factor in defining their ethnic identity. On the contrary, they believe that it is also affected by factors not related to language. Additionally, results reveal that misguided judgments about the supremacy and powerfulness of standard languages are inversely related to the views that the same speakers hold about non-standard languages and dialects. The findings of the present study suggest that the linguistic identity of young people in Cyprus is shifting, and this shift may have implications on issues related to language policy and planning, currently under discussion.
\end{abstract}

\section{Keywords}

Language Attitudes, Perceptions, Language and Ethnic Identity

Language Policy, Language Emancipation

\section{Introduction}

Language attitudes have drawn the attention of several researchers in fields such as linguistics, psychology, sociology and biology. Proposed views and theories are diverse and no one model is either conclusive or exhaustive. For example, the tripartite view offered by Rosenberg and Hovland (1960) proposes that atti- 
tudes contain cognitive, affective, and behavioral components. These are viewed as a part of general attitudes, as well as attitudes towards languages and dialects. More recent empirical research does not support clear distinctions between these three components and additionally, attitudes do not remain consistent throughout time (Eagly \& Chaiken, 1998). Consequently, views and attitudes are constantly being evaluated, re-assessed and are eventually changed.

Language attitudes are individual, group beliefs, preferences and desires about language (Baker, 1992; Wolfram et al., 1999) and "they can have a profound effect on the socio-political position of a language or a variety of language in a society" (Nolan, 2013: p. 153). Language attitudes have an influence on people's lives-their education, their self-esteem, and employment opportunities (Papapavlou \& Pavlou, 2001: p. 499). Baker (1992: p. 13) illustrates that attitude comprises three major components of language as follows: "cognition, affect and readiness for action." However, attitudes are difficult to measure because there might be lack of harmony between these components. Although behaviour is "observable and based on overtly expressed beliefs, this may not convey the true deep-seated feelings of a person" (Nolan, 2013: p. 153).

Lambert et al. (1960: p. 44), argue that spoken language is an identifying feature of a group and a person's attitude towards a group should generalize to the language that they use, and according to Pedersen (2010: p. 129), "there is a continual interplay between language attitudes and social factors". For Schiffman (1996: p. 5), the concept of linguistic culture is necessary to fully understand the language policy environment in any sociolinguistic situation. It is the set of behaviours, assumptions, cultural forms, prejudices, folk belief systems, attitudes, stereotypes, ways of thinking about language and religio-historical circumstances associated with a particular language. That is, the belief that a speech community has about language and its language in particular is part of the social conditions that affect the maintenance and transmission of its language.

Recent studies on language attitudes show that a lay person's attitudes toward languages and dialects are basically social value judgments. Some linguists find value judgments as lacking scientific verification and propose several methodological approaches for studying this sociolinguistic phenomenon. Three methodological approaches have been repeatedly used in studying attitudes. The first consists of direct measures such as questionnaires, interviews, polls, etc. The second includes indirect measures such as the "matched-guise technique" and the "magic boxes" and the third is called the "discourse analytic method" where the researcher undertakes a content analysis of discourse whereby they examine how people treat a linguistic variety within society (Ryan et al., 1988).

\section{Aims of the Present Study}

The present study attempts to investigate whether the value-laden views held by people are just broad social judgments or whether such judgments are erroneous stances and perpetuated myths held towards languages and their function. It is believed that misguided views or judgments about standard languages corres- 
pond negatively to the attitudes held toward dialects and non-standard languages. That is, when languages are accorded with high status and legendary dimensions that emanate from invalid and distorted convictions, then one might expect that dialects are substandard codes, inferior means of communication and inept in language education. It is to this direction that this study has been designed for, in an attempt to untangle this complex matter and offer insights for further examination.

\section{Review of Studies Pertaining to the Cypriot Linguistic Scene}

The landscape of the Cyprus linguistic setting has been intensely examined by various researchers in the last twenty years (Papapavlou, 2004, 2010; Karyolemou, 2001, 2004; Papapavlou \& Pavlou, 2001, 2005; Yiakoumetti, 2006; Tsiplakou et al., 2006; Ioannidou, 2009, 2012; Yiakoumetti \& Esch, 2010; Yiakoumetti \& Mina, 2011; Rowe \& Grohmann, 2013). For historical, political and other reasons, the linguistic scene in Cyprus is highly complex, politicized, ethnocentric (from Hellenocentric thinking to Cypriocentric thinking) and emotionally charged.

The continuous use of the standard form reinforces "ethnic pride" and patriotism. "Nations with ethnocentric cultures, especially those with long histories, normally promote national literacy while modern nations that have fewer ethnocentric tendencies generally advocate multiple literacies" (Pavlou \& Papapavlou, 2004: p. 114). Giles et al. (1977) maintain, the history of a language along with its prestige value and whether it has undergone standardization, may be sources of pride or even shame for members of a linguistic community, and "may again facilitate or inhibit the vitality of a given ethnolinguistic group (p. 312)".

Specifically, for Cyprus, two main dialects are spoken on the island, namely, Cypriot Greek and Cypriot Turkish. On the southern part of the island, Standard Modern Greek (henceforth SMG) is used, as the standard form, and Cypriot Greek (CG), as the regional dialect form. The first contact between the mother and child takes place in CG (Yiakoumetti, 2003) and CG is used mainly for oral communication in informal settings like the home and other friendly gatherings. On the other hand, SMG is the medium of instruction in schools and is mainly used in formal situations. Undoubtedly, this diglossic, bidialectal (or bilectal) situation has an enormous impact on Cypriots' ethnic identity and heavily affects language policy and language planning matters. Bidialectal programs have been proposed in Cyprus since 2000s (Papapavlou, 2010; Yiakoumetti \& Esch, 2010; Yiakoumetti \& Mina, 2011). These are viewed by the authors asoptimally suited for the Cyprus linguistic scene. However, as it is widely known, introducing bidialectal programs in education is not an entirely linguistic matter or concern. As Papapavlou (2010) states: "while currently the educational authorities in Cyprus may not be ready to accept yet major language policy changes, feasible options do exist and viable programs can be constructed for meeting the educational needs of a given policy (p. 121)." In support to the above, the European 
Union advocates for language equality and it is a major proponent of bilingual, dialectal (mother-tongue education) and bidialectal education in the European context. One of the European founding principles is to ensure the preservation of linguistic diversity and heritage (Yiakoumetti, 2003).

We must also note that the English language adds its own significance on the linguistic setting of Cyprus, and further perplexes the situation by (a) the influx of many English loanwords in the local native codes (in CG and SMG), especially in new technologies, commerce and business, (b) code-switching/code mixing to and from English, and (c) the increasing number of individuals with native command of English, including repatriated Cypriots, members of the Armenian, Maronite and other communities living in Cyprus (see McEntee-Atalianis \& Pouloukas, 2001). Furthermore, an increased number of Cypriot children attending English-speaking private schools from kindergarten to high school have been reported in the Ministry of Education annual reports. A large number of teachers employed in these private institutions have a native command of English and are holders of overseas (mainly British) qualifications.

In over viewing the major views held about the Cypruslinguistic setting, no attempt is made at present to define or prescribe the perceptions and sensitivities that researchers have expressed on this issue. Instead, the following proposed outline or diagram sketches major authors' views that have sprung from their research and published studies on the Cyprus linguistic landscape. This schematic representation (see Table 1) reviews: a) the setting, b) the speakers' usage, c) the status, d) official policy, e) attitudinal stances and f) the names of researchers proposing these positions. This schematic representation should not be taken as impervious and absolute; views may cross-over from one classification to the next. As one might expect, research on the issue is fast-growing and thus, further delimitations may be added to the proposed schematic representation.

Table 1. Proposed diagram of the Cypriot linguistic landscape in its current form.

\begin{tabular}{|c|c|c|c|c|c|}
\hline Setting & Diglossic & $\begin{array}{c}\text { Dialectal- } \\
\text { monodialectal }\end{array}$ & Bidialectal & (Discreet) bilectal & Dialect continuum \\
\hline Speakers' usage & High vs. Low & $\begin{array}{l}\text { Speakers use CG } \\
\text { exclusively }\end{array}$ & $\begin{array}{l}\text { Speakers use CG and SMG } \\
\text { with various competencies }\end{array}$ & $\begin{array}{l}\text { Speakers use local } \\
\text { vernacular and } \\
\text { official language }\end{array}$ & $\begin{array}{l}\text { From SMG-CG to } \\
\text { (acrolectal to mesolectal } \\
\text { to basilectal) }\end{array}$ \\
\hline Status & $\begin{array}{l}\text { Standard is High } \\
\text { and Dialect is Low }\end{array}$ & Low, Stigmatized & $\begin{array}{l}\text { Varies according to code } \\
\text { used }\end{array}$ & $\begin{array}{l}\text { Co-overt vs overt } \\
\text { prestige }\end{array}$ & $\begin{array}{l}\text { From Low to High } \\
\text { with intermediate } \\
\text { levels ( } 3 \text { to } 4 \text { ) }\end{array}$ \\
\hline Official policy & $\begin{array}{l}\text { Promotes the } \\
\text { standard }\end{array}$ & $\begin{array}{l}\text { Does not encourage } \\
\text { use of CG dialect }\end{array}$ & $\begin{array}{l}\text { Does not support } \\
\text { bidialectal education }\end{array}$ & Not considered yet & $\begin{array}{l}\text { Advocates the use } \\
\text { of acrolectal levels }\end{array}$ \\
\hline $\begin{array}{l}\text { Attitudinal } \\
\text { stances }\end{array}$ & $\begin{array}{l}\text { Positive toward } \\
\text { the standard code }\end{array}$ & $\begin{array}{l}\text { Usually negative } \\
\text { toward the dialect }\end{array}$ & $\begin{array}{l}\text { Increased appreciation of } \\
\text { CG }\end{array}$ & $\begin{array}{l}\text { Both } \mathrm{CG} \text { and } \mathrm{SMG} \\
\text { are not stigmatized }\end{array}$ & $\begin{array}{l}\text { Acrolectal levels } \\
\text { receive higher levels } \\
\text { of praise }\end{array}$ \\
\hline $\begin{array}{l}\text { Researchers } \\
\text { supporting } \\
\text { these positions }\end{array}$ & Sciriha (1995) & Newton (1972) & $\begin{array}{l}\text { Papapavlou \& Pavlou, } \\
(1998,2005) \text {; Pavlou } \\
\text { \& Christodoulou (2001); } \\
\text { Yiakoumetti et al. (2005); } \\
\text { Yiakoumetti (2006) }\end{array}$ & $\begin{array}{l}\text { Rowe \& } \\
\text { Grohmann (2013); } \\
\text { Rowe \& } \\
\text { Grohmann (2014) }\end{array}$ & $\begin{array}{l}\text { (Karyolemou, 2001) } \\
\text { Tsiplakou et.al., 2006; } \\
\text { Ioannidou (2009, } \\
\text { 2012) }\end{array}$ \\
\hline
\end{tabular}




\section{Method}

For the purposes of the present research study, the authors have followed the principles of quantitative research techniques in data collection and analysis, asking for the opinions of participants on certain issues pertaining to language use, language attitudes and the relation between language and identity.

\subsection{Participants}

Ninety-three (93) students ( $74 \%$ females and $26 \%$ males), between ages 18 - 24 (with average age of 20) attending courses at the Language Centre of the University of Cyprus were randomly selected (from a pull of 320 students registered for English classes). They are all enrolled in degree programs in various departments of the university; they come from all districts of the Republic of Cyprus and have a similar educational and socioeconomic background. It is noted that three (3) participants were excluded since they are not Cypriot nationals (thus, they may not be fully cognizant of the Cyprus linguistic setting).

\subsection{Material}

A specifically-designed questionnaire was developed for the purposes of the present study and was presented for completion in SMG (see Appendix A for a copy of the questionnaire). It comprises of two sections, with 5-point Lickertscale statements. Section 1 elicits demographic information (participants' age, gender, place of birth and residence, and field of study) and Section 2, consists of the following three subsections:

1) Subsection A includes 10 general statements reflecting on natural languages, their function and importance.

2) Subsection $B$ includes 10 statements on whether certain languages are simpler or harder, structurally or lexically complex and with, or without enriched vocabularies.

3) Subsection C includes forty statements (ten in each subsection) on how participants (a) appraise the linguistic competencies of CG speakers, (b) view the functions of CG by itself and in comparison to SMG, (c) evaluate the impact of CG in shaping (or not) ethnic Cypriot identity and (d) consider CG as an appropriate code for inclusion in education.

The draft questionnaire was piloted by six students (being similar with students intended to complete the task), who were instructed to comment on the clarity of the instructions and the lucidity of the sixty statements, as well as reporting on the length of task completion. On the basis of their comments, the questionnaire was modified in its present form.

\subsection{Procedures}

Having received permission from the Director of the Language Centre to carry out the study in language classes, the questionnaires were distributed in class by lecturers, who instructed students to fill them in and return them to the secretary of the Centre; the completed questionnaires were delivered to the experi- 
menters.

\section{Results}

The questionnaires were codified, negative statements were reversed and all answers were entered into the SPSS 21 and R 3.1.3 packages for statistical analyses. The sixty answers to the statements in all parts were turned from a 5-point Lickert scale into two category values, by collapsing values 1 and 2, 4 and 5 into a single category and retaining the middle value (3). It is noted that the nature of Lickert-scale answers necessitates the use of non-parametric statistical tests.

\subsection{Statistical Analyses}

In order to show participants' agreement or disagreement on factors under investigation, mean values were placed in five tables. Regarding the answers to Section A, which includes general statements on the nature of languages, the following findings are important for presentation.

Figure 1 shows the agreement/disagreement on whether language is a mirror of society and a powerful mean of communication.

It can be clearly seen in Figure 1 that the majority of participants $(81.72 \%)$ are in full agreement about the impact of language on society as well as being a powerful means of communication.

Figure 2 shows the agreement/disagreement on whether language is vibrant and constantly developing.

Figure 2 indicates that the majority of participants $(87.10 \%)$ are in agreement with the language continuously develops and serves as an essential part for daily communication.

Figure 3 illustrates the agreement/disagreement on how much language reflects the way humans think and their intelligence.

A lesser agreement is seen in Figure 3 (56.91\%) on whether language mirrors our way of thinking and the nature of our intelligence.

Figure 4 shows the agreement/disagreement on whether language reflects the cultures of a country.

In Figure 4, we can see that a larger proportion than in the previous three

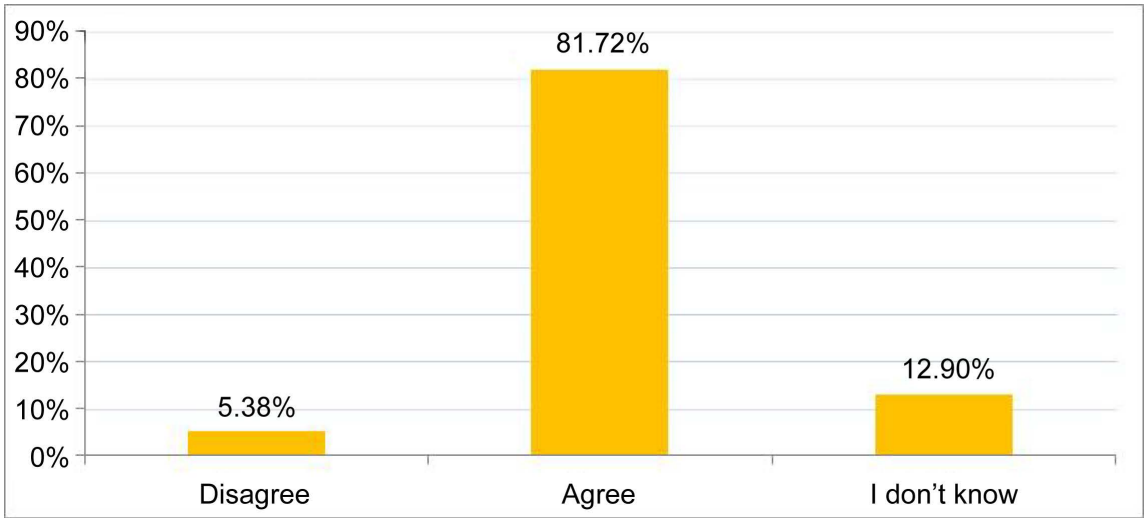

Figure 1. Agreement/disagreement on language mirroring of society. 


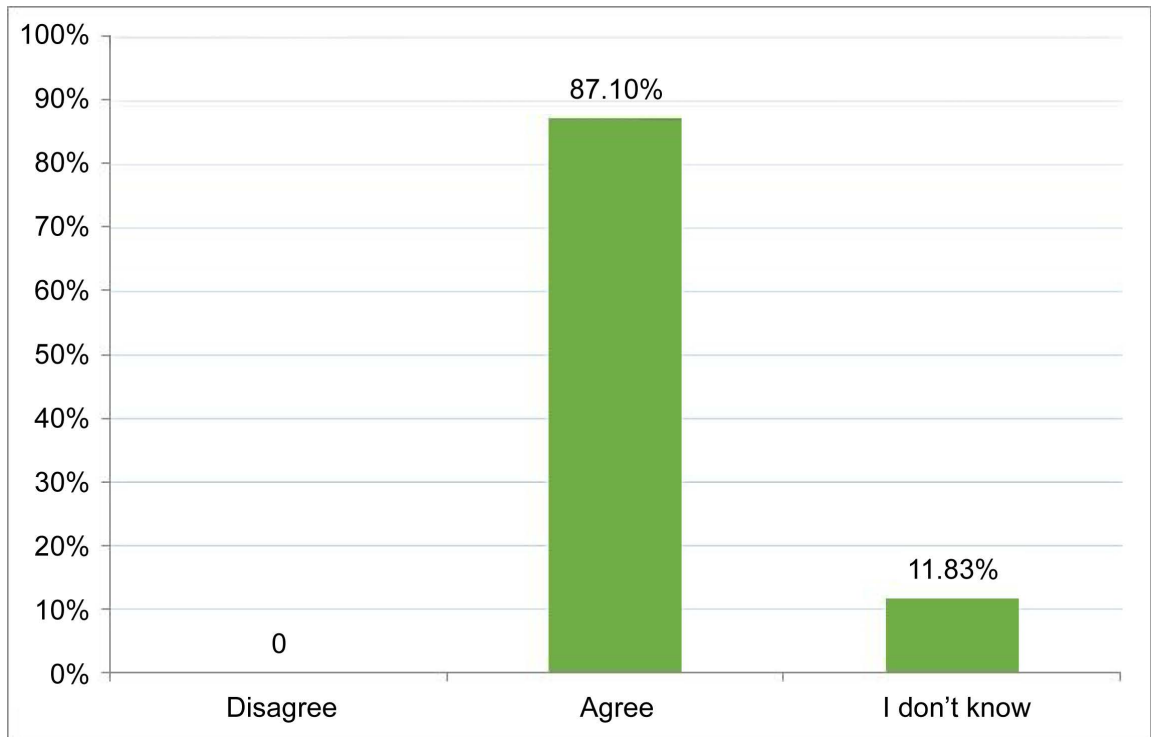

Figure 2. Agreement/disagreement on the development of language.

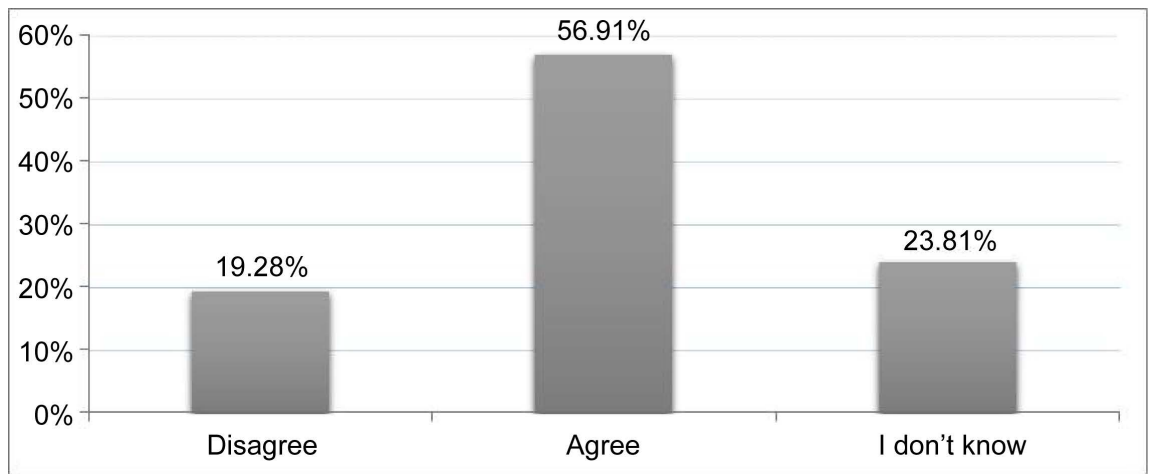

Figure 3. Agreement/disagreement on language affecting human thinking.

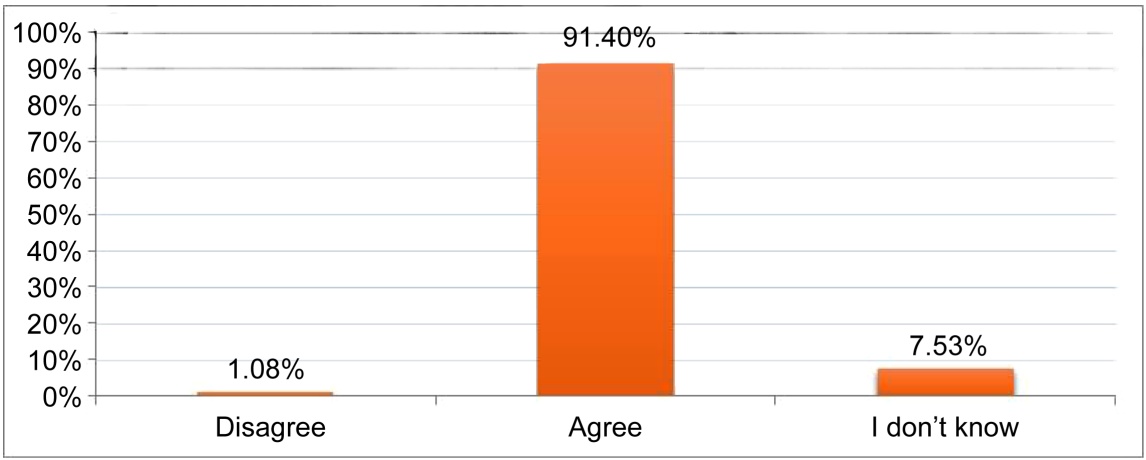

Figure 4. Agreement/disagreement on language reflecting culture.

tables, the majority of participants $(91.40 \%)$ are in strong agreement that language encapsulates the essence of cultures of a given society.

Figure 5 shows the agreement on whether language is the only factor defining ethnic identity.

Figure 5 illustrates that three quarters of participants (77.74\%) disagree with the view that language is the only factor defining ethnic identity. 


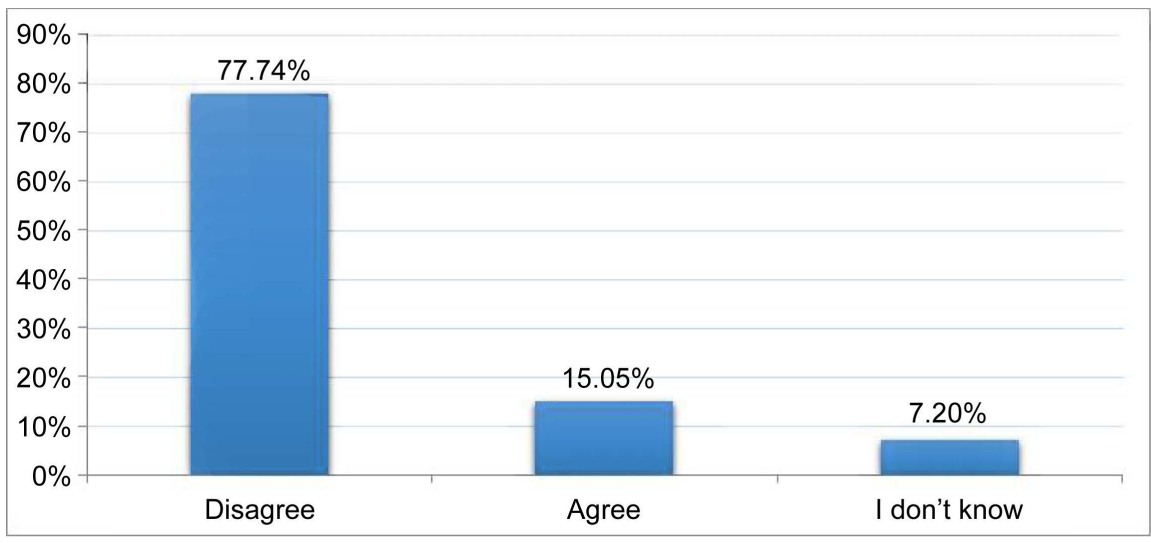

Figure 5. Degree of agreement on language defining ethnic identity.

In synthesizing the above results, we can say that participants, in their majority, believe that languages are: 1) a mirror of society and a robust means of communication, 2) a reflection of the cultures of a given country, 2) constantly evolving and adjusting to the needs of a society, and 3) an image of our way of thinking and interacting in society. However, participants do not agree that language is the only factor in defining their ethnic identity. On the contrary, it can be argued that language is undeniably affected by factors not related to language.

Beyond the above descriptive analyses, an attempt is made to examine whether the distorted views and invalid convictions about language are related/correlated with participants' perceptions about the Cypriot Greek variety presented in section C (1, 2, 3, and 4). Four non-parametric Pearson chi-square tests were carried out in order to test whether participants' convictions were linked with any of the four aspects of CG previously presented. The chi-square tests indicate whether the two independent samples (convictions about language and aspects of CG) have significant different distribution across categories (disagree/agree). Precisely, the tests carried out show whether the frequency obtained in the cells of tables are different from the frequencies we might have expected based on chance variation alone (Tuckman, 1978: p. 274).

Data in the two-variable case were cast into four contingency charts, showing the cohesiveness (or not) of convictions about language (CL) in comparison to four factors, namely:

(a) linguistic competencies of CGs (LC)

(b) functionality of CG (FCG)

(c) shaping ethnic Cypriot identity (SECI)

(d) acceptance of CG's appropriateness in education (ACGAE)

In the following section, four charts are presented showing the obtained results. Chart 1 includes an agree/disagree format concerning convictions about language (CL) in comparison to linguistic competencies of CGs (LC).

The findings presented in Table 2, indicate that the convictions (perceptions, attitudes, stances) on language have an impact on participants' views on Greek Cypriots' linguistic competencies. The obtained inverse relationship is significant $(p$-value $<2.2 \mathrm{e}-16)$. 
Table 3 includes an agree/disagree format concerning convictions about language (CL) in comparison to the functionality of CG, (FCG).

The findings presented in Table 3, indicate that the convictions (perceptions, attitudes, stances) on language have an impact on participants' views on the functionality of CG. The obtained inverse relationship is significant ( $p$-value < 2.2e-16).

Table 4 includes an agree/disagree format concerning convictions about language $(\mathrm{CL})$ in comparison to the impact of CG in shaping ethnic Cypriot identity (SECI).

The findings presented in Table 4 indicate that the convictions (perceptions, attitudes, stances) on language have an impact on the shaping of participants' ethnic Cypriot identity. The obtained inverse relationship is significant ( $p$-value $<2.2 \mathrm{e}-16)$.

Table 5 includes an agree/disagree format concerning convictions about language (CL) in comparison to the acceptance of CG's appropriateness in education (ACGAE).

The findings presented in Table 5 indicate that the convictions (perceptions,

Table 2. Convictions about language (CL) in comparison to linguistic competencies of CGs (LC).

\begin{tabular}{|c|c|c|c|}
\hline & $\mathrm{CL}$ & LC & SUM \\
\hline Disagree & 169 & 365 & 534 \\
\hline Agree & 519 & 363 & 882 \\
\hline SUM & 688 & 728 & 1416 \\
\hline
\end{tabular}

$\mathrm{X}$-squared $=98.4806, \mathrm{df}=1, p$-value $<2.2 \mathrm{e}-16$.

Table 3. Convictions about language (CL) in comparison to the functionality of CG, (FCG).

\begin{tabular}{|c|c|c|c|}
\hline & $\mathrm{CL}$ & FCG & SUM \\
\hline Disagree & 169 & 492 & 661 \\
\hline Agree & 519 & 236 & 755 \\
\hline SUM & 688 & 728 & 1416 \\
\hline
\end{tabular}

$\mathrm{X}$-squared $=262.9932, \mathrm{df}=1, p$-value $<2.2 \mathrm{e}-16$.

Table 4. Convictions about language (CL) in comparison to the impact of CG in shaping ethnic Cypriot identity (SECI).

\begin{tabular}{c|c|c|c}
\hline \multicolumn{1}{c}{ CL } & \multicolumn{2}{c}{ SECI } & SUM \\
\cline { 2 - 3 } Disagree & 169 & 448 & 617 \\
Agree & 519 & 336 & 855 \\
SUM & 688 & 784 & 1472
\end{tabular}

$\mathrm{X}$-squared $=159.7475, \mathrm{df}=1, p$-value $<2.2 \mathrm{e}-16$. 
Table 5. Convictions about language (CL) in comparison to the acceptance of CG's appropriateness in education.

\begin{tabular}{c|c|c|c}
\hline \multicolumn{1}{c}{ CL } & \multicolumn{2}{c|}{ ACGAE } & SUM \\
\hline \multirow{nyyn}{*}{ Disagree } & 169 & 398 & 567 \\
Agree & 519 & 281 & 800 \\
SUM & 688 & 679 & 1,367 \\
\cline { 2 - 3 } & &
\end{tabular}

$\mathrm{X}$-squared $=163.2414, \mathrm{df}=1, p$-value $<2.2 \mathrm{e}-16$.

attitudes, stances) on language have an impact on the acceptance of CG's appropriateness in education. The obtained inverse relationship is significant ( $p$-value $<2.2 \mathrm{e}-16)$.

The overall findings in this section indicate strong and significant relationships between participants' convictions compared to the aforementioned factors. In their totality, the results strongly support the purpose of the present study (see Section on "Aims of the present study"), where it is hypothesized that misguided judgments about the potency and powerfulness of standard languages are a strong indication about the negativity that the same speakers have towards non-standard languages and dialects.

\section{Discussion and Conclusion}

The present study provides a brief overview of the research conducted on the Cyprus linguistic scene concerning CG, and the labels/descriptions that have been proposed at various times. Specifically, the current studyexamineswhether value-laden views held by people are simply broad social judgments or whether such attitudes are erroneous stances that people hold, concerning languages and their function. Thus, in interpreting the results, an effort is made to (a) evaluate the findings of the current study (b) bring to light whether distorted views about standard languages have a strong bearing on how individuals appreciate (or not) variation in language (a universal phenomenon) and (c) suggest further experimentation for the clarity of factors that are still prevailing in this matter.

As stated earlier, the status of CG as an officially recognised dialect in Cyprus has undergone certain changes. CG has official, though indeed limited, status through legislation, it appears to be in the process of language emancipation since its speakers use it in a more varied way, and in more contexts than they did in the past. Such developments may be viewed as emancipatory. The distorted views held by participants in the study seem to have an impact on their overall perceptions about the dialect, its speakers, its functionality and its use in education. Here, we can conclude that misguided beliefs or judgments about standard languages correspond negatively to the attitudes held toward dialects and nonstandard languages. More specifically, when languages are accorded high status and legendary dimensions, emanating from erroneous and distorted convictions, then, dialects are considered as inferior means of communication and inept in language education. That is, they are viewed as inappropriate and inept in lan- 
guage instruction.

The findings of the present study receive additional support by presenting phenomena related to language emancipation, recently observed in CG. As it has been shown in the current investigation, those individuals who do not hold distorted views about standard languages are also those who appreciate and value dialects and their use in all domains of usage, including education. Since these individuals are liberated by anachronistic and authoritative ideological stances about standard languages, they are also 'free' to see the use of language (mainly in lexical innovation) in diverse ways. These individuals, among other things, can (a) extend the meaning of existing words, (b) create novel nuances to archaic forms of words, (c) blend words coming from other languages spoken in the vicinity, (d) merge words deriving from both SMG and CG and (e) borrow and frequently use foreign words (or short sentences) in their speech or in writing. Some examples have been identified and are presented in Table 6.

This newly acquired freedom (from enslaved monolithic pontifications of the past) is perceived as a creative "game" that expands speakers' horizons, increases their tolerance for "otherness" and empowers their abilities for effective communication. Language specialists describe this phenomenon as language emancipation, which is a multi-faceted process, found in many languages and many areas around the globe. Thus, it can be argued that elevated acceptances of dialects could be considered as cases of 'nascent' language emancipation. Lindgren (2013: p. 12) observes "how attitudes towards dialectal variation can be changed so that the formerly more or less stigmatized features of dialects are enhanced

Table 6. Examples on the phenomena related to language emancipation.

\begin{tabular}{|c|c|c|c|}
\hline No & Term & Transcription & Translation \\
\hline 1. & 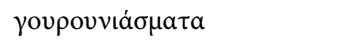 & / $\gamma$ urunazmata/ & eating like a pig \\
\hline 2 & $\pi \alpha ı \delta \rho \mu \dot{\alpha} v \tau \eta \lambda \alpha$ & /peðomadıla/ & children's wipes \\
\hline 3. & $\mu \omega \rho о \mu \alpha \dot{v} v \tau \eta \lambda \alpha$ & /moromadila/ & baby wipes \\
\hline 4. & Чаракобти́ & /psarakost1/ & fish eating for 40 days, during lent time \\
\hline 5. & 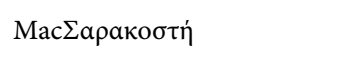 & /mak ${ }^{\mathrm{h}}$ sarakost1/ & eating Mc Donald's for 40 days, during lent time \\
\hline 6. & $\varphi \rho \circ \tau_{\varepsilon} \lambda \varepsilon \varepsilon{ }^{\prime}$ & /frutE:lion/ & perfectly-packaged fruit \\
\hline 7. & $\varphi \rho \varepsilon v \tau$ tou $\lambda i v \varepsilon \varsigma$ & /fredułınes/ & very good friends among females \\
\hline 8. & $\gamma \alpha \rho ı \delta о \pi о ́ \lambda \varepsilon \mu о \varsigma$ & / үarıðopolEmos/ & prawn brawl \\
\hline 9. & 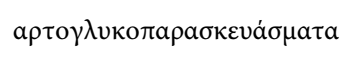 & /artoYlik $\mathrm{k}^{\mathrm{h}} \mathrm{p}^{\mathrm{h}}$ araskevazmata/ & pastries made with sweet bread \\
\hline 10. & show kaı $\alpha \beta \lambda \alpha \beta \dot{\varepsilon} \varsigma$ & /fouk ${ }^{\mathrm{h}}$ CavlavE:s/ & show and sound (instead of safe and sound) \\
\hline 11. & app $\lambda \dot{a}$-app $\lambda o ́$ & $\begin{array}{l}\text { /aph }{ }^{\mathrm{h}} \mathrm{la} / \\
/ \mathrm{ap} \mathrm{h} l \mathrm{l} /\end{array}$ & relevant to applying programs on cell phones \\
\hline 12. & $\mu \alpha \sigma \tau \imath \chi \omega \dot{\omega} \mu \alpha \tau \alpha$ & /ma:stixomata/ & chewing mastic \\
\hline 13. & 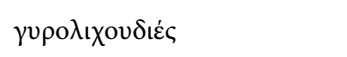 & /Yırolıxuðyes/ & gyro-roasted delicacy \\
\hline 14. & $\pi \rho \omega เ v a ́ \delta ı \kappa \alpha$ & /proinað $\mathrm{k}^{\mathrm{h}} \mathrm{a} /$ & TV morning shows \\
\hline 15. & $\gamma \kappa \lambda \alpha \mu o v \rho i \alpha ́$ & /glamurya/ & being or pretending to be glamorous \\
\hline
\end{tabular}


and their use is broadened to domains with more status". In conclusion, we may propose that the situation in CG meets many of the conditions outlined for language emancipation. However, drastic measures are required for the enhancement of language emancipation in Cyprus, especially if the "local" language is to be seriously considered for official use in education-an issue deliberated for over two decades on the island (Papapavlou, 2010). In conclusion, we acknowledge that the findings of the current study, which are based on the use of questionnaires, need to be augmented with the employment of other methodological approaches, for achieving the triangulation of results and thus, enabling researchers to offer well-sounding suggestions for decision-making.

\section{References}

Baker, C. (1992). Attitudes and Languages. Clevedon: Multilingual Matters.

Eagly, A. H., \& Chaiken, S. (1998). Attitude Structure and Function. In D. T. Gilbert, S. T. Fiske, \& G. Lindzey (Eds.), Handbook of Social Psychology (pp. 269-322). New York: McGraw-Hill.

Giles, H., Bourhis, R. Y., \& Taylor, D. (1977). Towards a Theory of Language in Ethnic Group Relations. In H. Giles (Ed.), Language, Ethnicity and Intergroup Relations (pp. 307-348). London: Academic Press.

Ioannidou, E. (2009). Using the "Improper" Language in the Classroom: The Conflict between Language Use and Legitimate Varieties in Education. Evidence from a Greek Cypriot Classroom. Language and Education, 23, 263-278. https://doi.org/10.1080/09500780802691744

Ioannidou, E. (2012). Language Policy in Greek Cypriot Education: Tensions between National and Pedagogical Values. Language, Culture and Curriculum, 25, 215-230. https://doi.org/10.1080/07908318.2012.699967

Karyolemou, M. (2001). From Liberalism to Legal Regulation: The Greek Language in Cyprus. Language Problems and Language Planning, 25, 25-52. https://doi.org/10.1075/lplp.25.1.03kar

Karyolemou, M., \& Goutsos, D. (2004). Introduction. The Sociolinguistics of Cyprus: Studies from the Greek sphere. International Journal of the Sociology of Language,168, $1-17$.

Lambert, W. E., Hodgson, R. C., Gardner, R. C., \& Fillenbaum, S. (1960). Evaluational Reactions to Spoken Language. Journal of Abnormal and Social Psychology, 60, 44-51. https://doi.org/10.1037/h0044430

Lindgren, A.-R. (2013). What Is Language Emancipation? Norwegian and Other Nordic Experiences. Sociolinguistic Studies, 7, 11-32. https://doi.org/10.1558/sols.v7i1-2.11

McEntee-Atalianis, L. J., \& Pouloukas, S. (2001). Issues of Identity and Power in a Greek-Cypriot Community. Journal of Multilingual and Multicultural Development, 22, 19-38. https://doi.org/10.1080/01434630108666423

Newton, B. (1972). Cypriot Greek: Its Phonology and Inflections. The Hague: Mouton. https://doi.org/10.1515/9783111634319

Nolan, J. S. (2013). The Results of a Nascent Language Emancipation in France: Perceptions of the Status and Future of Gallo in the Context of Its Inclusion in Brittany's Language Education Policy. Sociolinguistic Studies, 7, 151-166. https://doi.org/10.1558/sols.v7i1-2.151

Papapavlou, A. (1998). Attitudes toward the Greek Cypriot Dialect: Sociolinguistic Im- 
plications. International Journal of the Sociology of Language, 134, 15-28. https://doi.org/10.1515/ijsl.1998.134.15

Papapavlou, A. (2004). Verbal Fluency of Bidialectal Speakers of SMG and the Role of Language-in-Education Practices in Cyprus. International Journal of the Sociology of Language, 2004, 91-100. https://doi.org/10.1515/ijsl.2004.035

Papapavlou, A. (2010). Language Planning in Action: Searching for a Viable Bidialectal Program. Language Problems and Language Planning, 34, 120-140. https://doi.org/10.1075/lplp.34.2.02pap

Papapavlou, A., \& Pavlou, P. (1998). A Review of the Sociolinguistic Aspects of the Greek Cypriot Dialect. Journal of Multilingual and Multicultural Development, 19, 212-220. https://doi.org/10.1080/01434639808666353

Papapavlou, A., \& Pavlou, P. (2001). The Interplay of Language Use and Language Maintenance and the Cultural Identity of Greek Cypriots in the UK. International Journal of Applied Linguistics, 11, 92-113. https://doi.org/10.1111/1473-4192.00006

Papapavlou, A., \& Pavlou, P. (2005). Literacy and Language-in-Education Policy in Bidialectal Settings. Current Issues in Language Planning, 6, 164-181.

https://doi.org/10.1080/14664200508668279

Pavlou, P., \& Christodoulou, N. (2001). Bidialectalism in Cyprus and Its Impact on the Teaching of Greek as a Foreign Language. International Journal of Applied Linguistics, 11, 75-91. https://doi.org/10.1111/1473-4192.00005

Pavlou, P., \& Papapavlou, A. (2004). Issues of Dialect Use in Education from the Greek Cypriot Perspective. International Journal of Applied Linguistics, 14, 243-258. https://doi.org/10.1111/j.1473-4192.2004.00061.x

Pedersen, I. L. (2010). The Role of Social Factors in the Shaping of Language Attitudes-With an Evaluation of the Concept of Life Style. International Journal of the Sociology of Language, 2010, 129-150. https://doi.org/10.1515/ijsl.2010.033

Rosenberg, M. J., \& Hovland, C. I. (1960). Cognitive, Affective and Behavioral Components of Attitudes. In M. J. Rosenberg, \& C. I. Hovland (Eds.), Attitude Organization and Change: An Analysis of Consistency among Attitude Components. New Haven, CT: Yale University Press.

Rowe, C., \& Grohmann, K. K. (2013). Discrete Bilectalism: Towards Co-Overt Prestige and Diglossic Shift in Cyprus. International Journal of the Sociology of Language, 2013, 119-142. https://doi.org/10.1515/ijsl-2013-0058

Rowe, C., \& Grohmann, K. K. (2014). Canaries in a Coal Mine: Native Speakerhood and Other Factors as Predictors of Moribundity, Death, and Diglossic Shift in Cypriot Greek. Mediterranean Language Review, 21, 121-142.

Ryan, E. B., Howard, G., \& Miles, H. (1988). The Measurement of Language Attitudes. In U. Ammon, N. Dittmar, \& K. J. Mattheier (Eds.), Sociolinguistics. An International Handbook of the Science of Language and Society (Vol. 2), Berlin: Walter de Gruyter.

Schiffman, H. F. (1996). Linguistic Culture and Language Policy. London: Routledge.

Sciriha, L. (1995). The Interplay between Language and Identity in Cyprus. The Cyprus Review, 7, 7-34.

Tsiplakou, S. (2006) Cyprus: Language Situation. In K. Brown (Ed.), Encyclopedia of Language and Linguistics (2nd ed., pp. 337-339). Oxford: Elsevier.

Tsiplakou, S., Papapavlou, A., Pavlou, P., \& Katsoyannou, M. (2006). Levelling, Koineization and Their Implications for Bidialectism. In F. Hinskens (Ed.), Language Variation. European Perspectives. In Selected Papers from the 3rd International Conference on Language Variation in Europe (pp. 265-276). University of Amsterdam, 23-25 June 2005, Amsterdam/Philadelphia: John Benjamins. 
Tuckman, B. C. (1978). Conducting Educational Research. New York: Harcourt Brace Jovanovich.

Wolfram, W., Adger, C. T., \& Christian, D. (1999). Dialects in Schools and Communities. Mahwah, NJ: Lawrence Werlbaum Associates.

Yiakoumetti, A. (2003). Successful Application of a Language Awareness Learning Model Designed to Improve Performance in a Second Dialect (pp. 417-422). Cambridge: Cambridge Institute of Language Research.

Yiakoumetti, A. (2006). A Bidialectal Programme for the Learning of Standard Modern Greek in Cyprus. Applied Linguistics, 27, 295-317.

https://doi.org/10.1093/applin/aml012

Yiakoumetti, A., \& Esch, E. (2010). Educational Complexities Inherent in Bidialectal Communities and the Potential Contribution of the Common European Framework of Reference to Second-Dialect Development. In B. O’Rourke, \& L. Carson (Eds.), Language Learner Autonomy: Policy, Curriculum, Classroom. Contemporary Studies in Descriptive Linguistics(pp. 291-312). Oxford: Peter Lang.

Yiakoumetti, A., \& Mina, M. (2011). The Influence of First-Language Bidialectism in the Foreign-Language Classroom: Observations from Cyprus. Language, Culture and Curriculum, 24, 287-297. https://doi.org/10.1080/07908318.2011.620126

Yiakoumetti, A., Evans, M., \& Esch, E. (2005). Language Awareness in a Bidialectal Setting: The Oral Performance and Language Attitudes of Urban and Rural Students in Cyprus. Language Awareness, 14, 254-260. https://doi.org/10.1080/09658410508668840 


\section{Appendix I}

\section{Questionnaire}

\section{PART B}

In this part, you are asked to express your thoughts on language. Read the sentences which follow and state the level of your agreement to these statements (using a 1 - 5 scale).

\section{Totally disagree Disagree Uncertain $\underline{\text { Agree }}$ Totally agree 1 2 3

PART B (1)

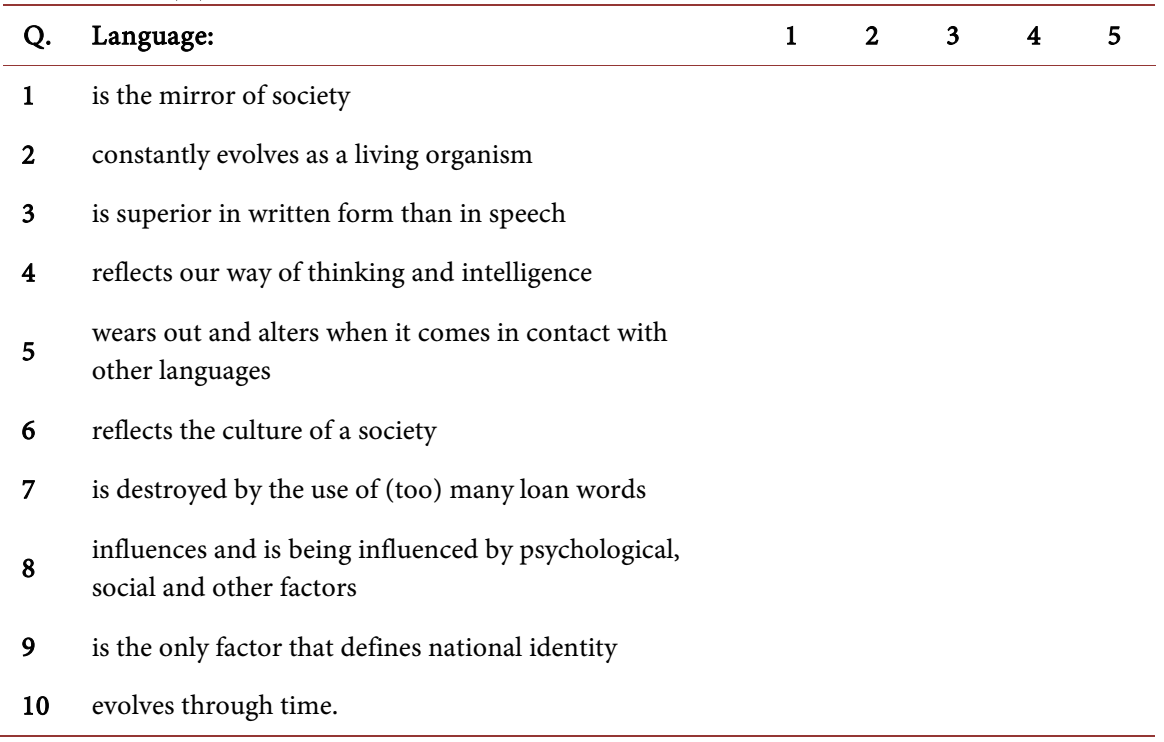

PART B (2)

Q. Some languages:

1 are naturally more difficult than other languages

2 provide the possibility of composing a rich literature whilst others do not

3 are naturally more complicated than other languages

4 are more melodious and romantic than others

5 are more commonly used than others in writing research/academic papers

6 have insufficient communication codes when it comes to the needs of the native speakers

7 have a poor vocabulary compared to other languages

8 have simpler grammatical structure compared to others

9 allow the expression of scientific ideas better than other languages

10 are less affected by languages and dialects compared to other languages 


\section{PART C}

In this part, you are asked to express your thoughts on the Cypriot Greek variety, in four aspects of the dialect (there are 10 statements for each aspect). Read the sentences which follow and state the level of your agreement to these statements (using a 1 - 5 scale).

\section{$\underline{\text { Totally disagree }}$ Disagree $\quad \underline{\text { Uncertain }}$ Agree $\underline{\text { Totally agree }}$ 1 2 3 4

\section{PART C (1)}

\begin{tabular}{|c|c|c|c|c|c|c|}
\hline Q. & $\begin{array}{l}\text { The use and the user of language } \\
\text { I believe the user of Cypriot Greek: }\end{array}$ & 1 & 2 & 3 & 4 & 5 \\
\hline 1 & can sufficiently cover all his/her linguistic needs & & & & & \\
\hline 2 & $\begin{array}{l}\text { has difficulty expressing his/her opinions because of } \\
\text { his/her language }\end{array}$ & & & & & \\
\hline 3 & cannot be creative neither in written nor spoken word. & & & & & \\
\hline 4 & $\begin{array}{l}\text { feels uncomfortable when he/she speaks in the presence } \\
\text { of Standard Modern Greek (SMG) speakers. }\end{array}$ & & & & & \\
\hline 5 & $\begin{array}{l}\text { when he/she speaks SMG within family or friends, } \\
\text { he/she sounds pretentious or ironic. }\end{array}$ & & & & & \\
\hline 6 & is able to express many complex and abstract concepts & & & & & \\
\hline 7 & is used extensively in social media & & & & & \\
\hline 8 & belongs only to rural and farming areas & & & & & \\
\hline 9 & does not believe in the superiority of SMG & & & & & \\
\hline 10 & can be creative and talented both in art and literature & & & & & \\
\hline
\end{tabular}

\section{PART C (2)}

\begin{tabular}{|c|c|c|c|c|c|c|}
\hline Q. & $\begin{array}{l}\text { Dialect functionality } \\
\text { I believe that the Cypriot Greek Dialect (C.G.D.): }\end{array}$ & 1 & 2 & 3 & 4 & 5 \\
\hline 1 & is a complete linguistic communication system & & & & & \\
\hline 2 & is an altered and corrupted linguistic system & & & & & \\
\hline 3 & $\begin{array}{l}\text { is an insufficient linguistic code, compared to Standard } \\
\text { Modern Greek (S.M.G.) }\end{array}$ & & & & & \\
\hline 4 & $\begin{array}{l}\text { is fully sufficient when it comes to the linguistic and } \\
\text { practical needs of the speakers }\end{array}$ & & & & & \\
\hline 5 & negatively affects the speakers' integration of thought & & & & & \\
\hline 6 & is an autonomously operating linguistic system. & & & & & \\
\hline 7 & is obscure to urban areas residents & & & & & \\
\hline 8 & $\begin{array}{l}\text { is only appropriate to be used in folklore events and } \\
\text { countryside affairs }\end{array}$ & & & & & \\
\hline 9 & $\begin{array}{l}\text { is an impaired linguistic code which lacks any special } \\
\text { literary value }\end{array}$ & & & & & \\
\hline 10 & $\begin{array}{l}\text { is an inadequate linguistic code which is going to die } \\
\text { out soon }\end{array}$ & & & & & \\
\hline
\end{tabular}


PART C (3)

Q. Language and Identity I believe that:

Cypriot Greek (CG) is important for maintaining the Cypriots' national identity

2 CG limits the development of cultural perceptions

3 Maintaining CG empowers the culture and civilization of Cyprus C.G is marginalized due to its absence in the official documents of the state

5 C.G is the familiar linguistic code of the country and the carrier of Cypriots' identity

6 C.G has been marginalized on purpose to prevent the development of the Cypriot consciousness and identity

7 C.G user has no significant education and hence is of lower social class

8 C.G is culturally related with the lower social classes

C.G user deviates from the basic values that govern the state/nation

10 The CG user does not have a clear national identity

\section{PART C (4)}

Q. Language Politics and Multilingualism I believe that:

1 CG should soon be promoted via particular language policies

2

CG should become one of the official languages of the Republic of Cyprus

3 someone can be a native speaker of CG and a native speaker of SMG equally

the acquisition of bidialectalism is similar to the acquisition of bilingualism people who use more than two languages in their daily life are confused or disoriented

6 multilingualism and multiculturalism of a state or a nation lead to national problems

7 a state/nation has to use one official language solely the use of CG affects negatively the language development of the children national identity 